\title{
Analysis of the dermatophyte Trichophyton rubrum expressed
} sequence tags

\author{
Lingling Wang ${ }^{\dagger 1}$, Li Ma ${ }^{\dagger 1}$, Wenchuan Leng ${ }^{\dagger 1}$, Tao Liu ${ }^{1}$, Lu Yu ${ }^{1}$, Jian Yang1, \\ Li Yang1, Wenliang Zhang1, Qian Zhang1, Jie Dong1, Ying Xue ${ }^{1}$, Yafang Zhu ${ }^{1}$, \\ Xingye $\mathrm{Xu}^{1}$, Zhe Wan ${ }^{2}$, Guohui Ding ${ }^{3}$, Fudong $\mathrm{Yu}^{3}$, Kang $\mathrm{Tu}^{3}$, Yixue $\mathrm{Li}^{3}$, \\ Ruoyu Li ${ }^{2}$, Yan Shen ${ }^{4}$ and Qi Jin*1,5
}

\begin{abstract}
Address: ${ }^{1}$ State Key Lab for Molecular Virology and Genetic Engineering, Beijing 100176, China, ${ }^{2}$ Research Centre for Medical Mycology, Beijing 100034, China, ${ }^{3}$ Bioinformatics Center, Shanghai Institutes for Biological Sciences, Chinese Academy of Sciences, Shanghai 200031, China, ${ }^{4}$ Chinese National Human Genome Center, Beijing, Beijing 100176, China and ${ }^{5}$ The Institute of Pathogen Microbiology, Chinese Academy of Medical Science, Beijing 100730, China

Email: Lingling Wang - linda_wing@yahoo.com; Li Ma - maryhmz@126.com; Wenchuan Leng - lengwenchuan@hotmail.com; Tao Liu - liutao0508@yahoo.com.cn; Lu Yu - Yu_lu0012@yahoo.com.cn; Jian Yang - yang@chgb.org.cn; Li Yang - Barbie_yl@sina.com; Wenliang Zhang - liangzi77@126.com; Qian Zhang - ZhangQian781116@yahoo.com.cn; Jie Dong - Jiedong1974@163.com; Ying Xue - xue_ying1001@yahoo.com.cn; Yafang Zhu - xyz810214@sina.com; Xingye Xu - xingye_xu0214@yahoo.com.cn; Zhe Wan - wan_zhe001@yahoo.com.cn; Guohui Ding - gwding@sibs.ac.cn; Fudong Yu - fdyu@sibs.ac.cn;

Kang Tu - TNinja1980@hotmail.com; Yixue Li - yxli@sibs.ac.cn; Ruoyu Li - lrymm@medmail.com.cn; Yan Shen - sheny@cdm.imicams.ac.cn; Qi Jin* - zdsys@vip.sina.com

* Corresponding author †Equal contributors
\end{abstract}

Published: II October 2006

BMC Genomics 2006, 7:255 doi:10.1/86/147|-2/64-7-255
Received: 21 May 2006

Accepted: II October 2006

This article is available from: http://www.biomedcentral.com//47|-2164/7/255

(C) 2006 Wang et al; licensee BioMed Central Ltd.

This is an Open Access article distributed under the terms of the Creative Commons Attribution License (http://creativecommons.org/licenses/by/2.0), which permits unrestricted use, distribution, and reproduction in any medium, provided the original work is properly cited.

\begin{abstract}
Background: Dermatophytes are the primary causative agent of dermatophytoses, a disease that affects billions of individuals worldwide. Trichophyton rubrum is the most common of the superficial fungi. Although $T$. rubrum is a recognized pathogen for humans, little is known about how its transcriptional pattern is related to development of the fungus and establishment of disease. It is therefore necessary to identify genes whose expression is relevant to growth, metabolism and virulence of $T$. rubrum.
\end{abstract}

Results: We generated 10 cDNA libraries covering nearly the entire growth phase and used them to isolate II,085 unique expressed sequence tags (ESTs), including 3,816 contigs and 7,269 singletons. Comparisons with the GenBank non-redundant (NR) protein database revealed putative functions or matched homologs from other organisms for 7,764 (70\%) of the ESTs. The remaining 3,321 (30\%) of ESTs were only weakly similar or not similar to known sequences, suggesting that these ESTs represent novel genes.

Conclusion: The present data provide a comprehensive view of fungal physiological processes including metabolism, sexual and asexual growth cycles, signal transduction and pathogenic mechanisms. 


\section{Background}

Dermatophytes, consisting of organisms in the Trichophyton, Epidermophyton, and Microsporum genera, are the primary etiologic pathogens of various dermatophytoses, such as tinea capitis, tinea corporis, tinea inguinalis, tinea manus, tinea unguium and tinea pedis. These infections are widespread and increasing in prevalence on a global scale. Indeed, in some geographic regions, dermatophyte infection is now considered a major public health concern.

Unlike other fungi, dermatophytes can cause infections in healthy, immune-competent individuals. Estimates suggest that 30 to $70 \%$ of adults are asymptomatic carriers of these fungi [1]. T. rubrum is the most common superficial fungus, accounting for at least $60 \%$ of all superficial fungal infections in humans. This organism may remain viable in the environment for over six months, thus accounting for widespread infections. Transmission occurs most often from person to person [2], for example, by shedding of infected skin cells and hair and by direct body contact [3].

Diagnosis of dermatophyte infections relies on clinical presentation, requiring successful isolation and culture and microscopy. It will take 2 to 4 weeks to culture and pleomorphic growth can lead to misidentification. Sometimes the morphological phenotype is not very stable. Rapid diagnostic tests using current molecular methodologies have been slow to develop for the dermatophytes [4].

Furthermore, despite the availability of new systemic antifungal therapies, nail infections are particularly difficult to eradicate, presenting a 25 to $40 \%$ recurrence rate [5]. Another increasing problem in clinical treatments is growing resistance to antifungal drugs. In the past decade, more and more cases of azole- and terbinafine-resistant fungal infections have been reported [6-8]. Ryder et al $[9,10]$ characterized at the molecular level the cause of the resistant phenotype of some clinical isolates, considering the resistance in some T. rubrum clinical isolates to terbinafine appears to be due to a single amino acid substitution in the gene squalene epoxidase.

T. rubrum is anthropophilic, specialized to infect humans, but rare animal infections have been reported. It is urease negative and vitamins independent. On the Bromcresol purple-(BCP)-milk solids glucose media, it shows restricted growth, no indicator color change for 10 to 14 days, then profuse growth with indicator change to purple (alkaline). Its teleomorph has not yet been found. Arthroconidia and mycelial fragments are the infectious agents. Excreted extracellular proteinase, alkaline serine proteinase, plays a role in dermatophytes growth and multiplica- tion as well as in the inflammatory reaction [2,11-13]. Thus, they are considered to be critical virulence factors for dermatophytes. There are many reports of the isolation and characterization of one or two proteases from an individual species of dermatophyte [14-18]. In T. rubrum, Some keratinases have been isolated and a subtilisin gene family were identified at the genetic level [19-22]. Jousson et al isolated a five-member secreted metalloproteases (MEP) family from genomic libraries of T. rubrum, T. mentagrophytes and $M$. canis. Further phylogenetic analysis revealed that the metalloproteases secreted by the three species in vitro are encoded by orthologous genes, strongly suggesting that the multiplication of an ancestral metalloprotease gene occurred prior to the dermatophyte species divergence [23]. However, only a small number of proteases from dermatophytes have been characterized at the genetic level.

Taken together, the lack of effective diagnostic and treatment strategies, the large number of individuals that experience dermatophyte infections, and the economic consequences highlight deficiencies in the research efforts aimed at understanding dermatophyte. T. rubrum is the most common superficial fungus, inducing dermatophytoses in various parts of the human skin, and can also cause deeper infections such as kerions, abscesses and granulomas. Research examining the pathogenesis of $T$. rubrum in numerous skin infections is needed in order to develop novel therapeutic agents and identify potential drug targets.

In the present study, we constructed various T. rubrum cDNA libraries and obtained 11,085 unique expressed sequence tags (ESTs). By analyzing these ESTs, we were able to further elucidate the physiological activities in metabolism, signal transduction, sexual life cycle, pathogenesis and cell wall composition of T. rubrum. These sequences provide an unparalleled resource for the future understanding of this remarkable fungus. Furthermore $T$. rubrum represents an attractive model species with which to study dermatophytes and other pathogenic filamentous fungi.

\section{Results and discussion \\ Expressed sequence tags sequence determination}

EST sequences were produced from 10 different cDNA libraries. After trimming for the vector and poor quality segments, a total of 34,670 sequences were identified and 11,085 unique ESTs were isolated. Isolated ESTs included 3,816 contigs and 7,269 singletons. All the constructed libraries, culture conditions and sequencing statistics employed in this study are summarized in table 1 . The average sequence length of these unique ESTs was 586 nucleotides (nt). Approximately 8,639 (78\%) of the unique ESTs were longer than $400 \mathrm{nt}$. 
Table I: Libraries, culture times, and sequencing statistics for ESTs generated in this study

\begin{tabular}{|c|c|c|c|c|c|c|}
\hline ID & Library Description & EST No. & GenBank Acc No. & Total & Reads in contigs & Reads in singletons \\
\hline 0 & $\begin{array}{l}\text { Spores incubated in YPG medium } \\
\text { for } 12 \text { hours }\end{array}$ & EST00I692-EST004492 & DW678211-DW681011 & 2801 & 1865 & 936 \\
\hline I & 10 days & EST004493-EST0I0729 & DW681012-DW687248 & 6237 & 5208 & 1029 \\
\hline 2 & 14 days & ESTOI0730-ESTOI5367 & DW687249-DW691886 & 4638 & 3946 & 692 \\
\hline 3 & 7 days & ESTOI5368-ESTOI732I & DW691887-DW693840 & 1954 & 1621 & 333 \\
\hline 4 & $\begin{array}{l}7,10,15,20 \text { and } 28 \text { days culture, } \\
\text { Subtracted library }\end{array}$ & EST017322-ESTO19168 & DW693841-DW695687 & 1847 & 1645 & 202 \\
\hline 5 & $7,10,16,22,26$ and 28 days & EST019169-EST020693 & DW695688-DW697212 & 1525 & 1207 & 318 \\
\hline 6 & 16,20 and 22 days & EST020694-EST023912 & DW697213-DW700431 & 3219 & 2267 & 952 \\
\hline 7 & 26 and 28 days & EST0239|3-EST030936 & DW700432-DW707455 & 7024 & 5562 & 1462 \\
\hline 8 & 34 and 36 days & EST030937-EST034670 & DW707456-DW711189 & 3734 & 2912 & 822 \\
\hline 9 & Spores & EST00000I-EST00I69I & DW405580-DW407270 & 1691 & 1168 & 523 \\
\hline
\end{tabular}

In the synthesis of the cDNA first strand, incomplete cDNA synthesis and/or 5' truncation of mRNA transcripts could lead to an overestimation of the gene number identified from our analysis. Accuracy of the estimation absolutely depends upon the quality of the library. Among the 7,764 matched ESTs, 1,439 could be matched to reference genes if the subjected starting site was set to be the first coding amino acid; meanwhile 2,325 matching genes could be found if the subjected starting site was allowed to be any of the first 10 amino acids. These data confirm that the quality of the libraries is reliable.

\section{Comparison to Non-redundant and Clusters of Orthologous Groups databases}

Identified ESTs were compared with the GenBank nonredundant (NR) protein database. This comparison enabled us to assign putative functions to or find homologs from other organisms for 7,764 (70\%) of the ESTs. The remaining 3,321 (30\%) ESTs were only weakly similar or not similar to known sequences ( $\mathrm{E} \geq 1 \mathrm{E}-05$ ), suggesting that they represent novel genes.

The comparative results for the ESTs with respect to the Clusters of Orthologous Groups (COGs) database, and its eukaryotic counterpart termed the KOGs database, are summarized in table 2. The ESTs identified herein contained a broad range of genes, predominantly encoding putative proteins involved in primary metabolism, gene expression, post-translation processes and cell structure. A significant proportion of the identified ESTs were matched to genes involved in transcription and signal transduction, suggesting that T. rubrum has an elaborate regulation system.

The COG collection currently consists of 138,458 proteins, which form 4873 COGs and comprise $75 \%$ of the 185,505 (predicted) proteins encoded in 66 genomes of unicellular organisms, including 3 Eukaryota, Saccharomyces cerevisiae, Schizosaccharomyces pombe and Encephalito- zoon cuniculi. The eukaryotic orthologous groups (KOGs) include proteins from 7 eukaryotic genomes: three animals (Caenorhabditis elegans, Drosophila melanogaster and Homo sapiens), one plant, Arabidopsis thaliana, two fungi (Saccharomyces cerevisiae and Schizosaccharomyces pombe), and the intracellular microsporidian parasite Encephalitozoon cuniculi. The current KOG set consists of 4852 clusters of orthologs, which include 59,838 proteins, or $\sim 54 \%$ of the analyzed eukaryotic 110,655 gene products [24]. Because the RNA processing in eukaryotic cells is more elaborated, and eukaryotic cells have some structures that prokaryotic cells lack, for example, nuclear and mitochondria, more genes involved in RNA processing and modification $[\mathrm{A}]$, chromatin structure and dynamics $[\mathrm{B}]$, cell cycle control, cell division, chromosome partitioning [D], nuclear structure $[\mathrm{Y}]$, cytoskeleton $[\mathrm{Z}]$ and intracellular trafficking, secretion, and vesicular transport [U] were identified in KOGs than COGs. The difference between gene number of class energy production and conversion [C] was mainly due to the mitochondrial related genes. On the contrary, more genes involved in cell motility $[\mathrm{N}]$, mainly encoding secretory pathway and cell motivity related proteins, were identified in COGs than KOGs. Meanwhile, the COG/KOG result was also affected by the subtle difference in functional classification to function similar proteins, especially transporters.

\section{Comparison of ESTs to those already available in GenBank} To date 3,749 T. rubrum ESTs have been released to GenBank by other research groups, most of which $(3,711)$ were obtained in condition mimicking virulence by Zaugg and Monod et al. When we compared these 3,749 previously reported ESTs to the NR database and to our EST pool, we found that 3,112 of the previously described ESTs in GenBank had matching homologs in other organisms in the NR database (E <1E-05) and that 637 ESTs were only weakly similar or did not match known sequences. Among the 3,749 ESTs identified previously, 2,738 ESTs matched 1,325 unique ESTs in our data (E 
Table 2: The comparative results of ESTs to COGs and KOGs

\begin{tabular}{|c|c|c|c|c|c|}
\hline & Functional Classification & Numbers in COG & Percents in COG & Numbers in KOG & Percents in KOG \\
\hline & Information storage and processing & & & & \\
\hline J & $\begin{array}{l}\text { Translation, ribosomal structure and } \\
\text { biogenesis }\end{array}$ & 413 & $3.73 \%$ & 408 & $3.68 \%$ \\
\hline$A$ & RNA processing and modification & 21 & $0.19 \%$ & 165 & $1.49 \%$ \\
\hline $\mathrm{K}$ & Transcription & 378 & $3.41 \%$ & $|3|$ & $1.18 \%$ \\
\hline L & DNA replication, recombination and repair & 213 & $1.92 \%$ & 85 & $0.77 \%$ \\
\hline \multirow[t]{2}{*}{ B } & chromatin structure and dynamics & 32 & $0.29 \%$ & 48 & $0.43 \%$ \\
\hline & Cellular Processes and Signaling & & & & \\
\hline $\mathrm{D}$ & $\begin{array}{l}\text { Cell cycle control, cell division, chromosome } \\
\text { partitioning }\end{array}$ & 49 & $0.44 \%$ & 86 & $0.78 \%$ \\
\hline Y & Nuclear structure & 3 & $0.03 \%$ & 19 & $0.17 \%$ \\
\hline V & Defense mechanisms & 70 & $0.63 \%$ & 17 & $0.15 \%$ \\
\hline $\mathrm{T}$ & Signal transduction mechanisms & 240 & $2.17 \%$ & 209 & $1.89 \%$ \\
\hline M & Cell wall/membrane/envelope biogenesis & 152 & $1.37 \%$ & 37 & $0.33 \%$ \\
\hline $\mathrm{N}$ & Cell motility & 64 & $0.58 \%$ & I & $0.01 \%$ \\
\hline Z & Cytoskeleton & 45 & $0.41 \%$ & 95 & $0.86 \%$ \\
\hline W & Extracellular structures & & & 4 & $0.04 \%$ \\
\hline$\cup$ & $\begin{array}{l}\text { Intracellular trafficking, secretion, and vesicular } \\
\text { transport }\end{array}$ & 153 & $1.38 \%$ & 244 & $2.20 \%$ \\
\hline \multirow[t]{2}{*}{ O } & $\begin{array}{l}\text { Posttranslational modification, protein } \\
\text { turnover, chaperones }\end{array}$ & 345 & $3.11 \%$ & 424 & $3.82 \%$ \\
\hline & Metabolism & & & & \\
\hline $\mathrm{C}$ & Energy production and conversion & 365 & $3.29 \%$ & 315 & $2.84 \%$ \\
\hline G & Carbohydrate transport and metabolism & 409 & $3.69 \%$ & 188 & $1.70 \%$ \\
\hline $\mathrm{E}$ & Amino acid transport and metabolism & 669 & $6.04 \%$ & 343 & $3.09 \%$ \\
\hline $\mathrm{F}$ & Nucleotide transport and metabolism & 120 & $1.08 \%$ & 110 & $0.99 \%$ \\
\hline $\mathrm{H}$ & Coenzyme transport and metabolism & 179 & $1.61 \%$ & 118 & $1.06 \%$ \\
\hline I & Lipid transport and metabolism & 256 & $2.31 \%$ & 219 & $1.98 \%$ \\
\hline$P$ & Inorganic ion transport and metabolism & 402 & $3.63 \%$ & 118 & $1.06 \%$ \\
\hline \multirow[t]{2}{*}{ Q } & $\begin{array}{l}\text { Secondary metabolites biosynthesis, transport } \\
\text { and catabolism }\end{array}$ & 188 & $1.70 \%$ & $|3|$ & $1.18 \%$ \\
\hline & Poorly characterized & & & & \\
\hline $\mathrm{R}$ & General function prediction only & 844 & $7.61 \%$ & 530 & $4.78 \%$ \\
\hline \multirow[t]{2}{*}{$S$} & Function unknown & 219 & $1.98 \%$ & 154 & $1.39 \%$ \\
\hline & Total & 11085 & & & \\
\hline
\end{tabular}

$<1 \mathrm{E}-05$, identity ranges from $72 \%$ to $100 \%$ ), suggesting these data be somewhat redundant. The remaining 1,011 did not have matching homologs in our EST database, including 263 ESTs which had no homology whatsoever in the NR database. Meanwhile, 748 of the 1,011 ESTs obtained only in their research had some homology with sequences in the NR database $(\mathrm{E}<1 \mathrm{E}-05)$, while 620 ESTs appeared to be hypothetical proteins, predicted proteins or unnamed protein. Some secreted proteinases that were identified by Monod et al. were not identified in our study (i.e. subtilisin-like protease SUB4, dipeptidyl-peptidase
IV, leucine aminopeptidase 1, leucine aminopeptidase 2 and a putative secreted metalloprotease 4), suggesting that the condition in their research may be a more suitable environment to induce expression of these proteins. The proteinases subtilisin-like protease SUB1 and subtilisinlike protease SUB5 were expressed not only in the condition they mimicked but also in YPD media (see Additional file 1). By comparison with previous released ESTs, our data supply the information about gene expression in different conditions, advancing the current knowledge of T. rubrum transcriptome. 


\section{Metabolism and secondary metabolism Metabolic overview}

A large percentage of T. rubrum genes were annotated in glycolysis and oxidative phosphorylation systems, as expected from what is known from other aerobic filamentous fungi. Genes corresponding to the citrate cycle enzymes and to components of complexes I (NADH-CoQ reductase), II (Succinate-CoQ reductase), III (CoQ-Cytochrome $\mathrm{C}$ reductase), and IV (Cytochrome $\mathrm{C}$ oxidase) were identified. The presence of these genes reflects the fungus' ability to perform complete aerobic pyruvate degradation and oxidative phosphorylation.

The pathways involved in metabolizing mono- and disaccharides, such as glucose, fructose, mannose, and sucrose, as well as polysaccharide starch, were best represented in the identified ESTs. There were also a large number of membrane transporters for saccharides such as xylose and fucose. Among the identified ESTs, all aminoyl-tRNA synthases have been previously described with the exception of cyseine-tRNA synthase, of which only one contig was found to exhibit weak homology (C3495-Contig1, E value 0.00008). Comparison of our ESTs data to KEGG revealed that these proteins were probably involved in many amino acid metabolism pathways, including glutamate metabolism, alanine and aspartate metabolism, glycine, serine and threonine metabolism, methionine metabolism, cysteine metabolism, valine, leucine and isoleucine biosynthesis, lysine biosynthesis, arginine and proline metabolism, histidine metabolism, phenylalanine, tyrosine and tryptophan biosynthesis. Analysis of these pathways indicated that T. rubrum could itself synthesize lysine. It could synthesize some amino acids via amino acid synthetase including glutamate, glutamine, asparagine, cysteine, tryptophan and threonine, and it can also synthesize some other amino acids via amino transfer reactions. The primary lipids in T. rubrum are sterol and phospholipid. Our analysis of the metabolic pathways in T. rubrum revealed that it can also synthesize co-enzymes such as riboflavin, nicotinate, nicotinamide, coenzyme A, ubiquinone, and folate. The genes probably involved in the synthesis of thiamine included: NMT1 protein, THI4 protein, ThiC protein and a putative ThiG protein. Because T. rubrum's vitamin independence serves to separate it from species such as Trichophyton violaceum that have vitamin requirements, identification of the ESTs involved in vitamin synthesis is of great significance for molecular diagnosis. Some ESTs probably involved in metabolism are included in additional files (see Additional file 2).

\section{Secondary metabolism}

Secondary metabolites are a remarkably diverse class of cellular products that often exhibit taxonomic specificity. Secondary metabolites are generally considered "nones- sential" for organismal growth in culture. In addition to the metabolic pathways mentioned above, there are also several secondary metabolic pathways present in $T$. rubrum. It has long been known that dermatophytes can survive in toxic environments, presumably through the production of biological tools to resist these toxins. Indeed dermatophytes have even been isolated from sewer water and polluted soil containing organic compounds such as aromatic compounds. The pathways implicated by the EST analysis are consistent with $T$. rubrum's capability to enzymatically degrade various toxins such as phenanthrene, dibenzofuran, ethylbenzene, styrene, fluorene, and 1,1,1-Trichloro-2,2-Bis-(4'-Chlorophenyl)Ethane(DDT) (see Additional file 3).

Similar to other pathogenic filamentous fungi, such as Magnaorthe grisea [25] and Aspergillus fumigatus [26], several important secondary metabolic products, were also found in T. rubrum; these included non-ribosomal peptide synthases, polyketide synthases, two putative dimethylallyl tryptophan synthases, a putative arsenate reductase and a hydrophobin. These gene products may be related to $T$. rubrum growth and pathogenicity. Polyketides (derived from polyketones) are a class of secondary metabolites produced by most organisms, but they have been most extensively examined in bacteria and fungi. In fungi, numerous functions have been proposed for polyketides, including the production of toxins $[27,28]$ and spore pigments [29,30]. Although it is well known that $T$. rubrum can produce pigments, the relationship between secondary metabolic pathways and pigments production remains unresolved. The various identified ESTs involved in secondary metabolism are listed in additional files (see Additional file 3).

Interestingly, T. rubrum harbors a putative sterigmatocystin biosynthesis monooxygenase StcW (C1113-Contig1), and a probable sterigmatocystin biosynthesis P450 monooxygenase STCL (Cytochrome P450 60B, EST000637, [GenBank:DW406216]), suggesting that it very likely may produce sterigmatocystin. However, confirmation of this possibility will require further investigation. Sterigmatocystin is of particular significance in evaluating the toxicity of T. rubrum products because prior evidence indicates that it is probably toxic to the human liver.

Although it is suspected that Trichophyton mentagrophytes can produce a penicillin-like substance [31], we did not find any evidence suggesting that T. rubrum generates antibiotic-like by-products.

\section{Signal transduction}

We also identified a variety of signal transduction systems in T. rubrum, such as MAPK, cAMP-dependent pathways, 
G-protein pathways, Ras pathways, and a large number of serine/threonine protein kinase/phosphatases and signal histidine kinases. Although the first four systems are generally conserved among fungal and mammalian species, the numbers and functions of signal transduction of histidine kinases vary between fungi. For example, in S. cerevisiae there exists only one, but in Neurospora crassa [32] there are 11 different histidine kinases. Indeed, there are many differences in the numbers and types of histidine kinases between filamentous fungi and yeast. Some experimental results [33-36] obtained with Candida albicans and Aspergillus fumigatus suggest that histidine kinases are related to fungal pathogenesis. In T. rubrum many ESTs are homologous to histidine kinases, some of which may be related to osmotic and nutrient responses. Several identified histidine kinases contain PAS/PAC domains, suggesting that they are involved in oxygen and light responses.

In addition to histidine kinase-related ESTs, we also identified Calcium-Calmodulin homologues and related proteins, suggesting that Ca-CaM pathways may be utilized by T. rubrum, similar to the model organism Neurospora crassa. Commonly, $\mathrm{Ca}^{2+}$ release from internal stores is mediated by the second messengers inositol-1, 4, 5-trisphosphate (InsP3) and cADP ribose, or by $\mathrm{Ca}^{2+}$-induced $\mathrm{Ca}^{2+}$ release [37]. Although InsP3 is present within Neurospora hyphae [38] and T. rubrum, Neurospora lack recognizable InsP3 receptors, ADP ribosyl cyclase and ryanodine receptor proteins, which are principal components of $\mathrm{Ca}^{2+}$ release mechanisms in plant and animal cells. These observations raise the question of whether there may be other second messenger systems that are responsible for $\mathrm{Ca}^{2+}$ release from internal stores that remain to be discovered in filamentous fungi. InsP3 receptors, ADP ribosyl cyclase or ryanodine receptor proteins were also not found in our EST data (the existence of these genes can only be determined after the whole genome is sequenced). Thus the mechanism of T. rubrum $\mathrm{Ca}-\mathrm{CaM}$ pathways remains to be determined. The various identified ESTs involved in signal transduction are listed in additional files (see Additional file 4).

\section{Sexual and asexual development}

Although the sexual life cycle has been described for Trichophyton mentagrophytes, Trichophyton ajelloi and Microsporum canis $[2,39]$, which are all heterothallic species, the sexual cycle of $T$. rubrum remains to be elucidated. We compared sexual-cycle related genes with those in other fungi, and our findings suggest that $T$. rubrum may be capable of sexual reproduction.

Sexual reproduction in ascomycete filamentous fungi is governed, in part, by two different mating-type genes that establish sexual compatibility: one gene encodes a protein with a high mobility group (HMG) domain, and the other encodes a protein with an alpha box domain (MAT). Such MAT containing genes are termed alpha mating-type genes. Homothallic fungi typically possess both matingtype genes and are self-fertilizing. Heterothallic fungi possess only one mating-type gene and require a partner with a different complementary mating-type gene. Although the MAT locus has not yet been found in T. rubrum, HMG is present (4 ESTs: EST000702, [GenBank:DW406281]; EST001404, [GenBank:DW406983]; EST004330, [GenBank:DW680849]; EST004146, [GenBank:DW680665]), and a large number of meiosis-related genes were identified in the ESTs, many of which were also found in Aspergillus niduluns and/or A. fumigatus. An analysis of 215 genes implicated in the fungal mating process, pheromone response, meiosis and fruiting body development revealed that many genes present in A. nidulans $[26,40,41]$ are also present in $T$. rubrum, including several genes for which the only known function is related to sexual reproduction (see Additional file 5). These results suggest that T. rubrum may also possess sexual cycles. However more in-depth exploration will be required in order to determine whether they indeed possess sexual cycles.

The current research on the fungal asexual development cycle primarily involves studies of Neurospora crassa and Aspergillus niduluns, and the literature contains two distinct models. Our comparison of the identified T. rubrum ESTs with the NR protein database, revealed a key enzyme (FlbD, EST023258, [GenBank:DW699777], E value 5E52) that is present in A. niduluns [41], but no key enzymes present in Neurospora crassa. Because in A. nidulans four proteins (FlbC, BrlA, AbaA and WetA) besides FlbD are also required in macroconidiation pathway, it is still unclear whether T. rubrum is more similar to A. niduluns or $N$. crassa with regards to asexual development.

\section{Extracellular proteinases}

The most evident dermatophyte feature is the ability to digest keratin. Dermatophytes can degrade human and other animal keratin protein and utilize it. This represents the pathogenic feature that differentiates dermatophytes from other fungi. The secreted proteinases of dermatophytes play an important role in the process of infection and are thus considered the primary virulent factors. However, only a few proteinase sequences have been identified thus far in T. rubrum [19-22,42-45]. In our data, secreted proteins were firstly analyzed by the NR comparison result. To the putative secreted protein identified in NR database, all of the corresponding ESTs were further subjected to SignalP prediction analysis. As to the ESTs listed in the Additional file 6, 48 of them were predicted to contain a signal peptide. Among the T. rubrum ESTs, identified secretory systems include type I, II, III and V, with type II, III being the most heavily represented. We also identified a large number of putative secretion related 
pathways and putative secreted proteinase, including some serine proteinases, aspartic protease, alkaline proteinase, peptidases and metalloprotease. (see Additional file 6 ). Among the serine proteinases, 10 unique ESTs were homologous to the known dermatophyte subtilisin-like serine protease family members SUB1, SUB5, and SUB6 [22]; meanwhile no identified ESTs were homologous to SUB2, SUB3, SUB4, or SUB7. The identity of the 6 serine protease ESTs with highest homology to T. rubrum serine proteinases varied from $80 \%$ to $93 \%$, suggesting that the genes may be selectively spliced, and/or the family may have other members, and/or that these genes have many copies in the genome.

Secreted metalloproteases are thought to be associated with lesion extension [15]. Recent reports [46] have identified a nitrogen regulating factor response region located upstream of the Microsporum canis MEP1 gene, consistent with the finding that, at the beginning of infection, there are only a few urea molecules, amino acids and glucose molecules available as a nutrient resource in sweat. Aspartic protease is an acid proteinase whereas secreted metal proteinase and subfamily members are neutral or basic proteinases. The presence of these proteinases supports the finding that initially $T$. rubrum can grow in either acidic or basic $\mathrm{pH}$ environments.

These proteinase and peptidase findings suggest that they may also be related to amino acid transportation. During T. rubrum infection, extracellular proteins are hydrolyzed into peptides by secreted proteinases then are further degraded into amino acids or dipeptides by peptidases and finally transported into cells. The identification of these proteinases and peptidases increases our understanding of the pathogenic mechanism underlying $T$. rubrum infection.

These secreted proteinases can not only degrade proteins such as keratin, elastin and collagen to supply nutrients to the fungi, but can also induce delayed-type hypersensitivity (such as with the SUB family and Tri r4) $[1,22]$. However, although the T. rubrum allergen Tri r4 EST shares 98\% homology with that in Trichophyton mentagrophytes, it is clear that the inflammation mediated by T. rubrum is not as severe as that induced by T. mentagrophytes. This is probably due, at least in part, to the presence of multiple inflammatory factors in T. mentagrophytes. When comparing the putative virulence factors present in T. rubrum with those in A. fumigatus [26] we also observed that many known virulence factors in A. fumigatus were not present in the identified T. rubrum ESTs. Likewise, many putative T. rubrum virulence factors were not found or were divergent in A. fumigatus. For example, the mep 1 gene exists in both A. fumigatus (Afu8g07080) and dermatophytes, but the two sequences were highly divergent (E value $5 e-26$ ).

\section{Cell wall}

The cell wall is a structure that humans lack but that fungi have. Therefore, the cell wall represents an ideal target for novel anti-fungal drugs. Many cell wall-related proteins were found among the presently identified ESTs, including chitin synthesis, chitinase, $\beta 1$,3-glucan synthase, $\beta 1,6$ glucan synthase, and 1,4-alpha-glucan branching enzyme. By analyzing the pathways involved in cell wall synthesis, it can be inferred that T. rubrum is probably capable of synthesizing peptidoglycan, the primary component of gram-positive bacteria. The principle enzymes involved in the peptidoglycan synthesis pathway UDP-N-acetylmuramoylalanyl-D-glutamyl-2, 6-diaminopimelate-Dalanyl-D-alanine ligase (EST020893, [GenBank:DW697412], GO:0008766) and phospho-N-acetylmuramoyl-pentapeptide-transferase (EST009048, [GenBank:DW685567], EC:2.7.8.13) were identified in our EST data. But it is still to be determined by experimental confirmation. We also identified some putative proteins that are likely to be involved in sterol synthesis, which is a primary target for clinically-available drugs. The components of the identified ESTs that are involved in cell wall synthesis are listed in table 3.

\section{Conclusion}

The estimated T. rubrum genome size is at least $22.05 \mathrm{Mb}$ [47]. And we estimate that a significant proportion of the gene content of $T$. rubrum is represented in this collection of sequences. Although ESTs can only represent genes that are actively expressed in particular phases, they complement the value of genomic sequencing through the functional identification of novel genes and provide information about gene structure and expression patterns [48-53]. Thirty percent of the 11,085 contigs and singletons identified in our analysis represent unique genes. Our Blast searches revealed that $33 \%$ of the 11,085 unique sequences possess matches in the yeast genome $(<e-5)$, suggesting that there are clear distinctions ( $67 \%)$ between yeast and filamentous fungi. These findings highlight the need for additional research on filamentous fungi.

In summary, although superficial fungi are the primary human pathogenic fungi, our knowledge about these organisms remains limited. T. rubrum represents an ideal model for the study of superficial fungi; our work in identifying ESTs in T. rubrum cDNA libraries will facilitate a greater understanding of the molecular mechanisms underlying its growth, metabolism, pathogenesis and drug resistance. In addition, our work may aid in the identification of novel effective drug targets and anti-fungal agents. 
Table 3: Cell-wall related genes in Trichophyton rubrum expressed sequence tags

\begin{tabular}{|c|c|c|c|}
\hline Contig/EST Number & GenBank Acc No. & E_value & Product \\
\hline Col33-Contigl & & $9.00 \mathrm{E}-08$ & chitin binding protein [Magnaporthe grisea] \\
\hline C02I0-Contigl & & I.00E-3। & I,3-beta-glucan biosynthesis protein, putative [Aspergillus fumigatus Af293] \\
\hline C0792-ContigI & & $4.00 \mathrm{E}-80$ & chitin synthase class VI [Coccidioides immitis] \\
\hline C0963-ContigI & & I.00E-117 & glucan synthase [Paracoccidioides brasiliensis] \\
\hline C0974-ContigI & & $2.00 \mathrm{E}-67$ & chitin biosynthesis protein (Chs5), putative [Aspergillus fumigatus Af293] \\
\hline Cl036-Contigl & & $\mathrm{I} .00 \mathrm{E}-08$ & beta-I,6-glucan boisynthesis protein (KnhI), putative [Aspergillus fumigatus Af293] \\
\hline Cl088-Contigl & & $6.00 \mathrm{E}-19$ & vegetative cell wall protein gPI [Aspergillus fumigatus Af293] \\
\hline CII27-ContigI & & $2.00 \mathrm{E}-95$ & class $V$ chitinase, putative [Aspergillus fumigatus Af293] \\
\hline CII92-Contigl & & $8.00 \mathrm{E}-28$ & chitin biosynthesis protein (Chs7), putative [Aspergillus fumigatus Af293] \\
\hline Cl439-Contigl & & I.00E-4I & chitin biosynthesis protein (Chs7), putative [Aspergillus fumigatus Af293] \\
\hline CI503-Contigl & & $8.00 \mathrm{E}-72$ & cell wall glucanase, putative [Aspergillus fumigatus Af293] \\
\hline CI548-ContigI & & $4.00 \mathrm{E}-29$ & beta-I,3-glucanosyltransferase 3 [Paracoccidioides brasiliensis] \\
\hline CI553-Contigl & & I.00E-73 & chitinase [Ajellomyces capsulatus] \\
\hline Cl6I2-Contigl & & $5.00 \mathrm{E}-87$ & beta $(\mathrm{I}-3)$ glucanosyltransferase 2 [Paracoccidioides brasiliensis] \\
\hline Cl924-Contigl & & $7.00 \mathrm{E}-66$ & cell wall glucanase (Scwl I), putative [Aspergillus fumigatus Af293] \\
\hline Cl945-Contigl & & I.00E-124 & I,4-alpha-glucan branching enzyme [Aspergillus fumigatus Af293] \\
\hline Cl994-Contigl & & $1.00 \mathrm{E}-103$ & beta-I,6 glucan synthetase (Kre6), putative [Aspergillus fumigatus Af293] \\
\hline C2050-ContigI & & 4.00E-77 & beta-I,3-glucanosyltransferase 3 [Paracoccidioides brasiliensis] \\
\hline C2307-ContigI & & $1.00 \mathrm{E}-106$ & $\begin{array}{l}\text { COG I 215: Glycosyltransferases, probably involved in cell wall biogenesis } \\
\text { [Pseudomonas fluorescens PfO-I] }\end{array}$ \\
\hline C2459-Contigl & & $5.00 \mathrm{E}-12$ & potential cell wall glycosidase [Candida albicans SC53I4] \\
\hline C2572-ContigI & & I.00E-120 & cell wall biogenesis protein phosphatase SsdI, putative [Aspergillus fumigatus Af293] \\
\hline C2766-ContigI & & $2.00 \mathrm{E}-24$ & COG3 I79: Predicted chitinase [Pseudomonas fluorescens PfO-I] \\
\hline C2907-ContigI & & I.00E-5I & $\begin{array}{l}\text { related to ECM4 protein (involved in cell wall biogenesis and architecture) } \\
\text { [Neurospora crassa] }\end{array}$ \\
\hline C3226-ContigI & & 0 & glucan synthase [Coccidioides posadasii] \\
\hline C33I5-ContigI & & $1.00 \mathrm{E}-19$ & I,3-beta-glucanosyltransferase, putative [Aspergillus fumigatus Af293] \\
\hline C3319-Contigl & & $3.00 \mathrm{E}-91$ & chitin synthase class VI [Coccidioides immitis] \\
\hline C3366-ContigI & & $2.00 \mathrm{E}-88$ & cell wall glucanase, putative [Aspergillus fumigatus Af293] \\
\hline C3375-Contigl & & $2.00 \mathrm{E}-68$ & I,3-beta-glucanosyltransferase Bgtl [Aspergillus fumigatus Af293] \\
\hline C3486-ContigI & & $1.00 \mathrm{E}-156$ & glucanosyltransferase GEL-I [Coccidioides posadasii] \\
\hline C35I0-ContigI & & $3.00 \mathrm{E}-12$ & GPI anchored cell wall protein, putative [Aspergillus fumigatus Af293] \\
\hline EST000306 & DW405885 & $3.00 \mathrm{E}-44$ & I,3-beta-glucanosyltransferase Gel2 [Aspergillus fumigatus Af293] \\
\hline EST00I65I & DW407230 & $2.00 \mathrm{E}-17$ & chitin synthase activator (Chs3), putative [Aspergillus fumigatus Af293] \\
\hline EST001838 & DW678357 & $3.00 \mathrm{E}-16$ & cell wall synthesis protein [Penicillium chrysogenum] \\
\hline EST00।87I & DW678390 & $4.00 \mathrm{E}-98$ & chitin synthase $\vee$ [Coccidioides immitis] \\
\hline EST002199 & DW678718 & $5.00 \mathrm{E}-16$ & beta-I,6 glucan synthetase (Kre6), putative [Aspergillus fumigatus Af293] \\
\hline EST002677 & DW679196 & $9.00 \mathrm{E}-11$ & cell wall synthesis protein [Penicillium chrysogenum] \\
\hline EST003205 & DW679724 & $2.00 \mathrm{E}-07$ & chitin deacetylase [Colletotrichum lindemuthianum] \\
\hline EST003442 & DW679961 & $6.00 \mathrm{E}-68$ & I,4-alpha-glucan branching enzyme [Aspergillus fumigatus Af293] \\
\hline
\end{tabular}


Table 3: Cell-wall related genes in Trichophyton rubrum expressed sequence tags (Continued)

\begin{tabular}{|c|c|c|c|}
\hline EST003782 & DW68030I & $5.00 \mathrm{E}-28$ & cell wall protein (PhiA), putative [Aspergillus fumigatus Af293] \\
\hline EST003793 & DW680312 & 4.00E-06 & related to chitinase 3 precursor protein [Neurospora crassa] \\
\hline EST005840 & DW682359 & I.00E-39 & vegetative cell wall protein gpI [Aspergillus fumigatus Af293] \\
\hline EST005855 & DW682374 & $2.00 \mathrm{E}-21$ & class $V$ chitin synthase [Coccidioides posadasii] \\
\hline EST006570 & DW683089 & 7.00E-48 & chitinase 6 [Coccidioides immitis] \\
\hline EST006839 & DW683358 & $3.00 \mathrm{E}-59$ & beta-I,6 glucan synthetase (Kre6), putative [Aspergillus fumigatus Af293] \\
\hline EST006926 & DW683445 & I.00E-26 & chitinase 3 [Coccidioides immitis] \\
\hline EST009330 & DW685849 & $2.00 \mathrm{E}-33$ & chitin synthase activator (Chs3), putative [Aspergillus fumigatus Af293] \\
\hline ESTOII70I & DW688220 & $4.00 \mathrm{E}-35$ & exo-beta-I,3-glucanase (ExgI), putative [Aspergillus fumigatus Af293] \\
\hline ESTOI 2488 & DW689007 & 7.00E-10 & class V chitinase, putative [Aspergillus fumigatus Af293] \\
\hline EST0I 3666 & DW690185 & I.00E-37 & chitinase [Aspergillus fumigatus] \\
\hline EST0I 3760 & DW690279 & I.00E-14 & cell wall glucanase, putative [Aspergillus fumigatus Af293] \\
\hline EST0I5346 & DW691865 & $4.00 \mathrm{E}-13$ & $\begin{array}{l}\text { Glucoamylase precursor (Glucan I,4-alpha-glucosidase) (I,4-alpha-D-glucan } \\
\text { glucohydrolase) }\end{array}$ \\
\hline EST0I7058 & DW693577 & $9.00 \mathrm{E}-15$ & $\begin{array}{l}\text { COG0463: Glycosyltransferases involved in cell wall biogenesis [Anabaena variabilis } \\
\text { ATCC 294I3] }\end{array}$ \\
\hline EST0I7I63 & DW693682 & $7.00 \mathrm{E}-42$ & class $V$ chitin synthase [Coccidioides posadasii] \\
\hline EST0I8650 & DW695169 & I.00E-64 & glucan synthase [Coccidioides posadasii] \\
\hline EST0I 8654 & DW695173 & $2.00 \mathrm{E}-14$ & class III chitin synthase [Coccidioides posadasii] \\
\hline EST0I8682 & DW695201 & $2.00 \mathrm{E}-09$ & cell wall biogenesis protein phosphatase SsdI, putative [Aspergillus fumigatus Af293] \\
\hline EST019188 & DW695707 & $2.00 \mathrm{E}-39$ & exo-beta-I,3-glucanase, putative [Aspergillus fumigatus Af293] \\
\hline EST0I9502 & DW696021 & $5.00 \mathrm{E}-21$ & chitin biosynthesis protein (Chs7), putative [Aspergillus fumigatus Af293] \\
\hline EST0। 9827 & DW696346 & $7.00 \mathrm{E}-55$ & chitinase 6 [Coccidioides immitis] \\
\hline EST019908 & DW696427 & $8.00 \mathrm{E}-17$ & chitin synthase activator (Chs3), putative [Aspergillus fumigatus Af293] \\
\hline EST019948 & DW696467 & $5.00 \mathrm{E}-\mathrm{II}$ & related to glucan I, 4-alpha-glucosidase [Neurospora crassa] \\
\hline EST02I575 & DW698094 & $2.00 \mathrm{E}-60$ & I,4-alpha-glucan branching enzyme [Aspergillus fumigatus Af293] \\
\hline EST021606 & DW698I25 & I.00E-3। & endo-1,3(4)-beta-glucanase, putative [Aspergillus fumigatus Af293] \\
\hline EST022805 & DW699324 & I.00E-07 & glucan synthase [Paracoccidioides brasiliensis] \\
\hline EST023। 34 & DW699653 & $5.00 \mathrm{E}-13$ & beta-I,3-glucanosyltransferase 3 [Paracoccidioides brasiliensis] \\
\hline EST024342 & DW70086I & $1.00 \mathrm{E}-110$ & COG0296: I,4-alpha-glucan branching enzyme [Pseudomonas fluorescens PfO-I] \\
\hline EST024896 & DW701415 & $2.00 \mathrm{E}-27$ & $\begin{array}{l}\text { I,4-alpha-glucan branching enzyme [Xanthomonas campestris pv. campestris str. } \\
\text { ATCC 339I3] }\end{array}$ \\
\hline EST025I 24 & DW701643 & $5.00 \mathrm{E}-62$ & $\begin{array}{l}\text { COG0463: Glycosyltransferases involved in cell wall biogenesis [Microbulbifer } \\
\text { degradans 2-40] }\end{array}$ \\
\hline EST027343 & DW703862 & $4.00 \mathrm{E}-17$ & endoglucanase, putative [Aspergillus fumigatus Af293] \\
\hline EST027819 & DW704338 & 8.00E-14 & GPI anchored cell wall protein, putative [Aspergillus fumigatus Af293] \\
\hline EST028I03 & DW704622 & I.00E-55 & glucan synthase [Coccidioides posadasii] \\
\hline EST029640 & DW706159 & I.00E-60 & class I chitin synthase [Coccidioides posadasii] \\
\hline EST031669 & DW708188 & $1.00 \mathrm{E}-60$ & chitinase [Aspergillus nidulans] \\
\hline EST0332। 4 & DW709733 & $4.00 \mathrm{E}-87$ & related to beta-I, 3-glucan binding protein [Neurospora crassa] \\
\hline EST033337 & DW709856 & $6.00 \mathrm{E}-8 \mathrm{I}$ & class V chitinase, putative [Aspergillus fumigatus Af293] \\
\hline EST033834 & DW710353 & $7.00 \mathrm{E}-81$ & class V chitinase, putative [Aspergillus fumigatus Af293] \\
\hline
\end{tabular}




\section{Methods \\ Preparation of strains and materials}

T. rubrum (strain BMU01672) and medium have been described previously [54].

\section{Preparation of cell cultures}

Preparation of hyphae cultures

A few hyphae of T. rubrum were inoculated on potato glucose agar and incubated at $27.5^{\circ} \mathrm{C}$ for $2 \sim 3$ weeks. In order to get cDNAs covering the entire growth phases, the hyphae were inoculated in liquid YPG medium $(10 \mathrm{~g} / \mathrm{L}$ yeast extract, $20 \mathrm{~g} / \mathrm{L}$ peptone, $10 \mathrm{~g} / \mathrm{L}$ D-glucose) and incubated in a $27.5^{\circ} \mathrm{C}$ bath shaker for $7,10,14,15,16,20,22$, $26,28,34$ and $36 \mathrm{~d}$, respectively. Combine the mycelium from $(7,10,15,20,28)(7,10,16,22,26,28),(16,20$, $22),(26,28)$, and $(34,36)$ days, thus get 8 samples (or mixtures) from $7,10,14,(7,10,15,20,28),(7,10,16$, $22,26,28),(16,20,22),(26,28),(34,36)$ day. All the samples or mixtures were used to construct unnormalized cDNA libraries except the mixture $(7,10,15,20,28)$, which was used to prepare the tester CDNA of a subtracted cDNA library. A large number of sequenced plasmids in 7 , 10 , and 14 days libraries were in vitro transcripted (Riboprobe $^{\circledast}$ in vitro Transcription Systems, Promega) and the RNA products were further reverse transcripted into the driver cDNA (Clontech PCR-Selected cDNA Subtraction Kit). The fungal samples (or mixtures) were centrifuged and the supernatant were discarded. The pelleted mycelium were washed twice with PBS.

\section{Preparation of spore cultures}

A few hyphae of T. rubrum were inoculated on potato glucose agar and incubated at $28^{\circ} \mathrm{C}$ for $2 \sim 3$ weeks. The spores were then washed by liquid YPG medium and filtered by cell filter to get rid of the hyphae. Part of the spores obtained were incubated in YPG medium at $28^{\circ} \mathrm{C}$ for 12 hours. Finally we got two samples, spores and incubated spores, respectively.

\section{Isolation and purification of total RNA and mRNA}

Total RNA and mRNA were isolated and purified as described previously [54].

\section{Construction of the cDNA library}

\section{Construction of the unnormalized CDNA library}

The 9 cDNA libraries ( 7 representing mycelium and 2 representing spores) were constructed following the protocols of the SUPERSCRIPT ${ }^{\text {тм }}$ Plasmid System with GATEWAY $^{\mathrm{TM}}$ Technology for cDNA Synthesis and Cloning (Invitrogen).

\section{Construction of the subtracted cDNA library}

The subtracted library was constructed following the protocols of the Clontech PCR-Selected cDNA Subtraction Kit. According to the instruction of the Kit, driver cDNA will be subtracted from the tester cDNA therefore a normalized library is constructed.

\section{Isolation and purification of plasmids, and sequencing of clones}

The cDNA plasmids were isolated as described previously [54]. Sequencing was performed with a generic T7 primer located 5' upstream of the inserted segments, following the protocol of the PRISM Big Dye Terminator Kit on an ABI3700 or MEGABACE automated sequencer.

\section{Bioinformatic analysis}

Sequence data processing, EST clustering and re-assembly

The processing method has been described previously [54].

EST analysis and construction of the metabolic pathway

The clustered EST consensus sequences were assigned with potential functions through homologous comparisons by BLASTX searches of the GenBank non-redundant (NR) protein database (07/2005), Gene Ontology (GO, 11/2005) and Yeast Genome Database (YGD, 11/2005). ESTs were further classified according to the NCBI Clusters of Orthologous Groups of Proteins database (COGs, 06/2005) and the Eukaryotic Orthologous Groups (KOGs, 06/2005). The metabolic pathways of T. rubrum were partially reconstructed by searching for known pathway homologs found in the Kyoto Encyclopedia of Genes and Genomes database (KEGG, 11/2004). Secreted proteins were analyzed by comparison to NR. All the threshold cutoff were $\mathrm{E}<1 \mathrm{E}-05$. As to the putative secreted protein identified in NR database, all of the corresponding ESTs were further subjected to SignalP prediction analysis.

\section{Accession numbers}

The sequences have been submitted to GenBank (accession numbers from [GenBank:DW405580] to [GenBank:DW407270] and from [GenBank:DW678211] to [GenBank:DW711189]). All the information about GenBank numbers, contigs assembly, and ESTs annotation could be obtained form our Trichophyton rubrum database [55].

\section{Authors' contributions}

LW performed construction of the cDNA gene libraries, clone isolation, plasmids sequencing, data analysis and drafted the manuscript. LM, WL performed construction of the cDNA gene libraries, clone isolation, and plasmids sequencing. TL, LY participated in the construction of the cDNA libraries and the isolation of clones. JY carried out the bioinformatics analysis and constructed the T. rubrum database. LY, WZ, QZ, JD, YX, YZ and XX participated in the library construction, clone isolation and plasmids sequencing. ZW and RL were responsible for the strain 
identification, culture and growth conditions design. GD, FY, KT and YL participated in bioinformatics analysis. QJ designed the project, supervised the research and revised the manuscript. SY cooperated with QJ and implemented the project and supervise the research in the center of Chinese National Human Genome Center. All authors read and approved the final manuscript.

\section{Additional material}

\section{Additional File 1}

ESTs Comparison.

Click here for file

[http://www.biomedcentral.com/content/supplementary/1471-

2164-7-255-S1.xls]

\section{Additional File 2}

metabolism overview.

Click here for file

[http://www.biomedcentral.com/content/supplementary/1471-

2164-7-255-S2.xls]

\section{Additional File 3}

secondary metabolism.

Click here for file

[http://www.biomedcentral.com/content/supplementary/1471-

2164-7-255-S3.xls]

\section{Additional File 4}

signal transduction.

Click here for file

[http://www.biomedcentral.com/content/supplementary/1471-

2164-7-255-S4.xls]

\section{Additional File 5}

Sexual and asexual development.

Click here for file

[http://www.biomedcentral.com/content/supplementary/1471-

2164-7-255-S5.xls]

\section{Additional File 6}

secreted proteins.

Click here for file

[http://www.biomedcentral.com/content/supplementary/1471-

2164-7-255-S6.xls]

\section{Acknowledgements}

The work was supported by The National High Technology Research and Development Program of China (Accession number: 200IAA22302I) and National Key Technologies R\&D Programme (Accession Number: 2002BA7IIAI4).

\section{References}

I. Woodfolk JA, Wheatley LM, Piyasena RV, Benjamin DC, Platts-Mills TE: Trichophyton antigens associated with IgE antibodies and delayed type hypersensitivity. Sequence homology to two families of serine proteinases. I Biol Chem 1998, 273:29489-29496.
2. Kane J, Summerbell R, Sigler L, Krajden S, Land G: Laboratory Handbook of Dermatophytes Star Publishing Company; 1997.

3. Kwon-Chung KJ, Bennett JE: Medical Mycology Lea \& Febiger, Philadelphia; 1992.

4. Kac G: Molecular approaches to the study of dermatophytes. Med Mycol 2000, 38:329-36.

5. Hay RJ: The future of onychomycosis therapy may involve a combination of approaches. $\mathrm{Br} J$ Dermatol 200I, I45(Suppl 60):3-8.

6. Mukherjee PK, Leidich SD, Isham N, Leitner I, Ryder NS, Ghannoum MA: Clinical Trichophyton rubrum Strain Exhibiting Primary Resistance to Terbinafine. Antimicrob Agents Ch 2003, 47:82-86.

7. Fernández-Torres B, Carrillo AJ, Martín E, Del Palacio A, Moore MK, Valverde A, Serrano M, Guarro J: In Vitro Activities of 10 Antifungal Drugs against 508 Dermatophyte Strains. Antimicrob Agents Ch 200I, 45:2524-2528.

8. Pujol I, Capilla J, Ferna'ndez-Torres B, Ortoneda M, Guarro J: Use of the Sensititre Colorimetric Microdilution Panel for Antifungal Susceptibility Testing of Dermatophytes. J Clin Microbiol 2002, 40:2618-2621.

9. Osborne CS, Leitner I, Favre B, Ryder NS: Amino Acid Substitution in Trichophyton rubrum Squalene Epoxidase Associated with Resistance to Terbinafine. Antimicrob Agents Ch 2005, 49:2840-2844.

10. Osborne CS, Leitner I, Hofbauer B, Fielding CA, Favre B, Ryder NS: Biological, Biochemical, and Molecular Characterization of a New Clinical Trichophyton rubrum Isolate Resistant to Terbinafine. Antimicrob Agents Ch 2006, 50:2234-2236.

II. Sanyal AK, Das SK, Banerjee AB: Purification and partial characterization of an exocellular proteinase from Trichophyton rubrum. Sabouraudia 1985, 23:165-178.

12. Collins JP, Grappel SF, Blank F: Role of keratinises in dermatophytosis. II. Fluorescent antibody studies with keratinase II of Trichophyton mentagrophytes. Dermatologica 1973, 146:95-100.

13. Grappel SF, Blank F: Role of keratinases in ermatophytosis. I. Immune responses of guinea pigs infected ith Trichophyton mentagrophytes and guinea pigs immunized with eratinases. Dermatologica 1972, 145:245-255.

14. Brouta F, Descamps F, Fett T, Losson B, Gerday C, Mignon B: Purification and characterization of a $43.5 \mathrm{kDa}$ keratinolytic metalloprotease from Microsporum canis. Med Mycol 200I, 39:269-275.

15. Brouta F, Descamps F, Monod M, Vermout S, Losson B, Mignon B: Secreted metalloprotease gene family of Microsporum canis. Infect Immun 2002, 70:5676-5683.

16. Tsuboi R, Ko IJ, Takamori K, Ogawa H: Isolation of a keratinolytic proteinase from Trichophyton mentagrophytes with enzymatic activity at acidic pH. Infect Immun 1989, 57:3479-3483.

17. Descamps F, Brouta F, Monod M, Zaugg C, Baar D, Losson B, Mignon $B$ : Isolation of a Microsporum canis gene family encoding three subtilisin-like proteases expressed in vivo. J Invest Dermatol 2002, I I 9:830-835.

18. Pierard G, Gerday C, Losson B: Purification and characterization of a $31.5 \mathrm{kDa}$ keratinolytic subtilisin-like serine protease from Microsporum canis and evidence of its secretion in aturally infected cats. Med Mycol 1998, 36:395-404.

19. Apodaca G, McKerrow JH: Purification and characterization of a 27,000-Mr extracellular proteinase from Trichophyton rubrum. Infect Immun 1989, 57:3072-3080.

20. Asahi M, Lindquist R, Fukuyama K, Apodaca G, Epstein WL, McKerrow $\mathrm{JH}$ : Purification and characterization of major extracellular proteinases from Trichophyton rubrum. Biochem J 1985, 232: |39-| 44.

21. Lambkin I, Hamilton AJ, Hay RJ: Purification and characterisation of a novel 34,000-Mr cell-associated proteinase from the dermatophyte Trichophyton rubrum. FEMS Immunol Med Microbiol 1996, 13:131-140.

22. Joussona $O$, Le'chennea B, Bontemsa $O$, Mignonb B, Reichardc $U$, Barbland J, Quadronid M, Monod M: Secreted subtilisin gene family in Trichophyton rubrum. Gene 2004, 339:79-88.

23. Jousson O, Le' chenne B, Bontems O, Capoccia S, Mignon B, Barblan J, Quadroni M, Monod M: Multiplication of an ancestral gene encoding secreted fungalysin preceded species differentiation in the dermatophytes Trichophyton and Microsporum. Microbiology 2004, 150:30I-310. 
24. Tatusov RL, Fedorova ND, Jackson JD, Jacobs AR, Kiryutin B, Koonin EV, Krylov DM, Mazumder R, Mekhedov SL, Nikolskaya AN, Rao BS, Smirnov S, Sverdlov AV, Vasudevan S, Wolf YI, Yin J], Natale DA: The COG database: an updated version includes eukaryotes. BMC Bioinformatics 2003, 4:41

25. Dean RA, Talbot NJ, Ebbole DJ, Farman ML, Mitchell TK, Orbach MJ, Thon M, Kulkarni R, Xu JR, Pan H, Read ND, Lee YH, Carbone I, Brown D, Oh YY, Donofrio N, Jeong JS, Soanes DM, Djonovic S Kolomiets E, Rehmeyer C, Li W, Harding M, Kim S, Lebrun MH, Bohnert H, Coughlan S, Butler J, Calvo S, Ma LJ, Nicol R, Purcell S, Nusbaum C, Galagan JE, Birren BW: The genome sequence of the rice blast fungus Magnaporthe grisea. Nature 2005, 434:980-986.

26. Nierman WC, Pain A, Anderson MJ, Wortman JR, Kim HS, Arroyo J, Berriman M, Abe K, Archer DB, Bermejo C, Bennett J, Bowyer P, Chen D, Collins M, Coulsen R, Davies R, Dyer PS, Farman M, Fedorova N, Fedorova N, Feldblyum TV, Fischer R, Fosker N, Fraser A, Garcia JL, Garcia MJ, Goble A, Goldman GH, Gomi K, Griffith-Jones S, Gwilliam R, Haas B, Haas H, Harris D, Horiuchi H, Huang J, Humphray S, Jimenez J, Keller N, Khouri H, Kitamoto K, Kobayashi T, Konzack S, Kulkarni R, Kumagai T, Lafon A, Latge JP, Li W, Lord A Lu C, Majoros WH, May GS, Miller BL, Mohamoud Y, Molina M, Monod M, Mouyna I, Mulligan S, Murphy L, O'Neil S, Paulsen I, Penalva MA, Pertea M, Price C, Pritchard BL, Quail MA, Rabbinowitsch E, Rawlins N, Rajandream MA, Reichard U, Renauld H, Robson GD, Rodriguez de Cordoba S, Rodriguez-Pena JM, Ronning CM, Rutter S, Salzberg SL, Sanchez M, Sanchez-Ferrero JC, Saunders D, Seeger K Squares R, Squares S, Takeuchi M, Tekaia F, Turner G, Vazquez de Aldana CR, Weidman J, White O, Woodward J, Yu JH, Fraser C Galagan JE, Asai K, Machida M, Hall N, Barrell B, Denning DW: Genomic sequence of the pathogenic and allergenic filamentous fungus Aspergillus fumigatus. Nature 2005, 438: I I I I-I I 56.

27. $\mathrm{Yu} \mathrm{JH}$, Leonard TJ: Sterigmatocystin biosynthesis in Aspergillus nidulans requires a novel type I polyketide synthase. J Bacterio 1995, I 77:4792-4800.

28. Feng GH, Leonard TJ: Characterization of the polyketide synthase gene (pksLI) required for aflatoxin biosynthesis in Aspergillus parasiticus. J Bacteriol 1995, 177:6246-6254.

29. Linnemannstons P, Schulte J, del Mar Prado M, Proctor RH, Avalos J, Tudzynski B: The polyketide synthase gene pks4 from Gibberella fujikuroi encodes a key enzyme in the biosynthesis of the red pigment bikaverin. Fungal Genet Biol 2002, 37: I34-I48.

30. Mayorga ME, Timberlake WE: The developmentally regulated Aspergillus nidulans wA gene encodes a polypeptide homologous to polyketide and fatty acid synthases. Mol Gen Genet 1992, 235:205-212.

31. Fischer JB, Kane J: The detection of contamination in Trichophyton rubrum and T. mentagrophytes. Mycopathol Mycol Appl |97|, 43:169-180.

32. Galagan JE, Calvo SE, Borkovich KA, Selker EU, Read ND, Jaffe D, FitzHugh W, Ma LJ, Smirnov S, Purcell S, Rehman B, Elkins T, Engels R, Wang S, Nielsen CB, Butler J, Endrizzi M, Qui D, lanakiev P, Bell-Pedersen D, Nelson MA, Werner-Washburne M, Selitrennikoff CP, Kinsey JA, Braun EL, Zelter A, Schulte U, Kothe GO, Jedd G, Mewes W, Staben C, Marcotte E, Greenberg D, Roy A, Foley K, Naylor J, StangeThomann N, Barrett R, Gnerre S, Kamal M, Kamvysselis M, Mauceli E, Bielke C, Rudd S, Frishman D, Krystofova S, Rasmussen C, Metzenberg RL, Perkins DD, Kroken S, Cogoni C, Macino G, Catcheside D, Li W, Pratt RJ, Osmani SA, DeSouza CP, Glass L, Orbach MJ, Berglund JA, Voelker R, Yarden O, Plamann M, Seiler S, Dunlap J, Radford A, Aramayo R, Natvig DO, Alex LA, Mannhaupt G, Ebbole DJ, Freitag M, Paulsen I, Sachs MS, Lander ES, Nusbaum C, Birren B: The genome sequence of the filamentous fungus Neurospora crassa. Nature 2003, 422:859-868.

33. Clemons KV, Miller TK, Selitrennikoff CP, Stevens DA: A putative histidine kinase as a virulence factor for systemic aspergillosis. Med Mycol 2002, 40:259-262

34. Pott GB, Miller TK, Bartlett JA, Palas JS, Selitrennikoff CP: The isolation of FOS-I, a gene encoding a putative two-component histidine kinase from Aspergillus fumigatus. Fungal Genet Biol 2000, 3 I:55-67.

35. Selitrennikoff CP, Alex L, Miller TK, Clemons KV, Simon MI, Stevens DA: COSI, a putative two-component histidine kinase of Candida albicans, is an vivo virulence factor. Med Mycol 200I, 39:69-74.

36. Torosantucci A, Chiani P, De Bernardis F, Cassone A, Calera JA, Calderone R: Deletion of the two-component histidine kinase gene (CHKI) of Candida albicans contributes to enhanced growth inhibition and killing by human neutrophils in vitro. Infect Immun 2002, 70:985-987.

37. Bootman MD, Collins TJ, Peppiatt CM, Prothero LS, MacKenzie L, De Smet P, Travers M, Tovey SC, Seo JT, Berridge MJ, Ciccolini F, Lipp P: Calcium signalling-an overview. Semin Cell Dev Biol 200I, 12:3-10

38. Lakin-Thomas PL: Effects of inositol starvation on the levels of inositolphosphatesandinositol lipids in Neurospora crassa. Biochem J I993, 292:805-8I I.

39. Weitzman I, Summerbell R: The Dermatophytes. Clin Microbiol Rev 1995, 8(2):240-259.

40. Machida M, Asai K, Sano M, Tanaka T, Kumagai T, Terai G, Kusumoto K, Arima T, Akita O, Kashiwagi Y, Abe K, Gomi K, Horiuchi H, Kitamoto K, Kobayashi T, Takeuchi M, Denning DW, Galagan JE, Nierman WC, Yu J, Archer DB, Bennett JW, Bhatnagar D, Cleveland TE, Fedorova ND, Gotoh O, Horikawa H, Hosoyama A, Ichinomiya M, Igarashi R, Iwashita K, Juvvadi PR, Kato M, Kato Y, Kin T, Kokubun A, Maeda H, Maeyama N, Maruyama J, Nagasaki H, Nakajima T, Oda K, Okada K, Paulsen I, Sakamoto K, Sawano T, Takahashi M, Takase K, Terabayashi Y, Wortman JR, Yamada O, Yamagata Y, Anazawa H, Hata Y, Koide Y, Komori T, Koyama Y, Minetoki T, Suharnan S, Tanaka A, Isono K, Kuhara S, Ogasawara N, Kikuchi H: Genome sequenceing and analysis of Aspergillus oryzae. Nature 2005, 438: || $157-|| 6 \mid$

41. Galagan JE, Calvo SE, Cuomo C, Ma LJ, Wortman JR, Batzoglou S, Lee SI, Basturkmen M, Spevak CC, Clutterbuck J, Kapitonov V, Jurka J, Scazzocchio C, Farman M, Butler J, Purcell S, Harris S, Braus GH, Draht O, Busch S, D'Enfert C, Bouchier C, Goldman GH, Bell-Pedersen D, Griffiths-Jones S, Doonan JH, Yu J, Vienken K, Pain A, Freitag M, Selker EU, Archer DB, Penalva MA, Oakley BR, Momany M, Tanaka T, Kumagai T, Asai K, Machida M, Nierman WC, Denning DW, Caddick M, Hynes M, Paoletti M, Fischer R, Miller B, Dyer P, Sachs MS, Osmani SA, Birren BW: Sequencing of Aspergillus nidulans and comparative analysis with $\boldsymbol{A}$. fumigatus and $\boldsymbol{A}$. oryzae. Nature 2005, 438: II05-III5.

42. Samdani AJ, Dykes PJ, Marks R: The proteolytic activity of strains of $T$. mentagrophytes and $T$. rubrum isolated from tinea pedis and tinea unguium infections. I Med Vet Mycol 1995, 33:167-170.

43. Apodaca G, McKerrow JH: Expression of proteolytic activity by cultures of Trichrophyton rubrum. J Med Vet Mycol 1990, 28: $|59-| 7 \mid$.

44. Apodaca G, McKerrow JH: Regulation of Trichophyton rubrum proteolytic activity. Infect Immun 1989, 57:308I-3090.

45. Meevootisom V, Niederpruem DJ: Control of exocellular proteases in dermatophytes and especially Trichophyton rubrum. Sabouraudia 1979, 17:91-106.

46. Yamada T, Makimura K, Hirai A, Kano R, Hasegawa A, Uchida K, Yamaguchi $\mathrm{H}$ : Isolation of a region of a secreted metalloprotease gene from Microsporum canis. Jpn J Infect Dis 2004 57:25-28.

47. Cervelatti EP, Ferreira-Nozawa MS, Aquino-Ferreira R, Fachin AL, Martinez-Rossi NM: Electrophoretic molecular karyotype of the dermatophytes Trichophyton rubrum. Genet Mol Biol 2004, 27:99-102.

48. Goffeau A, Barrell BG, Bussey $H$, Davis RW, Dujon B, Feldmann H, Galibert F, Hoheisel JD, Jacq C, Johnston M, Louis EJ, Mewes HW, Murakami Y, Philippsen P, Tettelin H, Oliver SG: Life with 6000 genes. Science 1996, 274:546, 563-567.

49. Posada-Buitrago ML, Frederick RD: Expressed sequence tag analysis of soybean rust pathogen Phakopsora pachyrhizi. Fungal Genet Biol 2005, 42:949-962.

50. Brown DW, Cheung F, Proctor RH, Butchko RA, Zheng L, Lee Y, Utterback T, Smith S, Feldblyum T, Glenn AE, Plattner RD, Kendra DF, Town CD, Whitelaw CA: Comparative analysis of 87,000 expressed sequence tags from the fumonisin-producing fungus Fusarium verticillioides. Fungal Genet Biol 2005, 42:848-86।.

51. Sacadura NT, Saville BJ: Gene expression and EST analysis of Ustilago maydis germination teliospores. Fungal Genet Biol 2003, 40:47-64.

52. Jones T, Federspiel NA, Chibana H, Dungan J, Kalman S, Magee BB, Newport G, Thorstenson YR, Agabian N, Magee PT, Davis RW, Scherer S: The diploid genome sequence of Candida albicans. Proc Natl Acad Sci 2004, I 0 I:7329-7334.

53. Braun BR, van Het Hoog M, d'Enfert C, Martchenko M, Dungan J, Kuo A, Inglis DO, Uhl MA, Hogues H, Berriman M, Lorenz M, Levitin A, 
Oberholzer U, Bachewich C, Harcus D, Marcil A, Dignard D, louk T, Zito R, Frangeul L, Tekaia F, Rutherford K, Wang E, Munro CA, Bates S, Gow NA, Hoyer LL, Kohler G, Morschhauser J, Newport G, Znaidi S, Raymond M, Turcotte B, Sherlock G, Costanzo M, Ihmels J, Berman J, Sanglard D, Agabian N, Mitchell AP, Johnson AD, Whiteway M, Nantel A: A human-curated annotation of the Candida albicans genome. PLoS Genet 2005, I:36-57.

54. Wang L, Ma L, Leng W, Yang J, Zhu J, Dong J, Xue Y, Zhe W, Li R, Jin Q: Analysis of part of the Trichophyton rubrum ESTs. Sci China C Life Sci 2004, 47:389-395.

55. Trichophyton rubrum database [http://www.mgc.ac.cn/Trubrum/ ]

Publish with Biomed Central and every scientist can read your work free of charge

"BioMed Central will be the most significant development for disseminating the results of biomedical research in our lifetime. " Sir Paul Nurse, Cancer Research UK

Your research papers will be:

- available free of charge to the entire biomedical community

- peer reviewed and published immediately upon acceptance

- cited in PubMed and archived on PubMed Central

- yours - you keep the copyright

Submit your manuscript here:

http://www.biomedcentral.com/info/publishing_adv.asp
BioMedcentral 